\title{
A quantitative model of reticulo-rumen particle degradation and passage
}

\author{
BY A. LIRETTE* AND L. P. MILLIGAN† \\ Department of Animal Science, University of Alberta, Edmonton, Alberta T6G 2P5, Canada
}

(Received 12 August 1988-Accepted 17 April 1989)

\begin{abstract}
Labelled particles were prepared by mordanting low concentrations $(0 \cdot 1$ or $5 \mathrm{~g} / \mathrm{kg}$ dry matter) of chromium to neutral-detergent-extracted stems (1-2 mm or $10 \mathrm{~mm}$ in length) of bromegrass (Bromus inermis). These were used in the study of reticulo-rumen particle kinetics of four steers given bromegrass hay and from the results a quantitative model of particle digestion and passage was developed. At the $0-1 \mathrm{~g} \mathrm{Cr} / \mathrm{kg}$ concentration there was minimal interference with digestibility of the feedstuff. The ratio, dry weight of the reticulo-rumen large-particle pool $(>3.35 \mathrm{~mm})$ : small-particle pool $(<3.35 \mathrm{~mm})$ was 2:1. It was derived from the model that volatile fatty acids (VFA) and carbon dioxide in the rumen were produced mainly from large particles, and that between 500 and $700 \mathrm{~g} / \mathrm{kg}$ hay dry matter was digested in the reticulo-rumen. It was also derived from the model that a major portion, 200 (SE 110) $\mathrm{g} / \mathrm{kg}$, of the hay dry matter was rapidly solubilized and that the material leaving the reticulo-rumen was composed of small particles $(500-840 \mathrm{~g} / \mathrm{kg})$, large particles $(100-160 \mathrm{~g} / \mathrm{kg})$ and an unknown portion of soluble dry matter of hay $(0-400 \mathrm{~g} / \mathrm{kg})$. Disappearance from the large-particle pool in the model involving the lowest $\mathrm{Cr}$ level was directed to formation of VFA and $\mathrm{CO}_{2}(0.68$ (SE 0.04) of total flow) to the small-particle pool (0.25 (SE 0.06) of total flow) and direct passage from the reticulo-rumen (0.07 (SE 0.002) of total flow). The disappearance from the small-particle pool was to VFA and $\mathrm{CO}_{2}$ production and to the omasum accounting for 0.14 (SE 0.18 ) and 0.86 (SE 0.24 ) respectively, of the total flow. It was concluded that the low-level-mordanting technique in combination with appropriate sampling yielded a realistic quantitative description of forage breakdown and movement processes in the digestive tract of cattle.
\end{abstract}

Particulate kinetics: Reticulo-rumen model

Clearance of feed residues from the reticulo-rumen has long been recognized as a major process determining and, therefore, controlling intake and digestion of forages and, as a result, productive performance of the ruminant (Faichney, 1986). Clearance depends on two interacting processes: the first being breakdown through the physical reduction in particle size plus microbial digestion, and the second being physical passage from the reticulo-rumen. Although the qualitative aspects of clearance processes are well understood, increased use of mathematical models to examine control processes and increasing interest in manipulating rumen dynamics to improve efficiency depends on understanding the quantitative importance of these processes (Ulyatt et al. 1986).

Until now the best estimates of the rates of clearance of particles from the rumen have been made using indigestible or undigested material. However, use of such material does not yield a measure of the outflow of digestible nutrients, which probably would be intermediate between the flow pattern of fluids and solids (Church, 1979).

Chromium mordanting fulfils most of the desirable criteria for particulate marking. It yields a stable marker of solids forming hexacoordinate ligands with hydroxyl groups that are very difficult to hydrolyse (Uden et al. 1980). Cr mordanted to fibre is the most tenaciously bound of the particulate markers which have been examined (Ellis et al. 1980).

Present addresses: * Department of Animal Science, Nova Scotia Agricultural College, Truro, Nova Scotia B2N 5E3, Canada, $\uparrow$ Department of Animal and Poultry Science, University of Guelph, Guelph, Ontario NIG 2W1, Canada. 
Concentrations of $\mathrm{Cr}$ in excess of $80 \mathrm{mg} / \mathrm{g}$ dry matter (DM) render plant cell walls essentially indigestible (Colucci, 1979); as the content of $\mathrm{Cr}$ on the fibre decreases, the digestibility of fibre increases. Moreover, $\mathrm{Cr}$ bound to feedstuffs at high levels has been found to affect the rate of passage, probably due to altered specific gravity (Ehle, 1984).

The objective of the present work was to evaluate low-Cr-concentration mordanting of neutral-detergent-extracted forage particles as a means to attain marked particles that will yield biologically realistic measurements of particle kinetics in the rumen.

\section{MATERIALS AND METHODS}

Animals, diets and management

Four 15-month old Hereford steers weighing approximately $400 \mathrm{~kg}$ were prepared with rumen fistulas of $100 \mathrm{~mm}$ diameter. Each animal was maintained in an individual metabolism crate with continuous lighting at ambient temperatures of $20-22^{\circ}$ for 2 weeks before and during the experiment. Bromegrass hay (Bromus inermis) harvested at mid- to late-bloom, was chopped through a $76 \mathrm{~mm}$ screen and offered at $2 \mathrm{~h}$ intervals using an automatic feeding device. Body-weight was maintained by providing $450 \mathrm{~g}$ hay DM each $2 \mathrm{~h}$. Composition ( $/ \mathrm{kg} \mathrm{DM}$ ) of the diet was $13.9 \mathrm{~g}$ nitrogen, $672 \mathrm{~g}$ cell-wall constituents (neutral-detergent fibre; NDF) and $349 \mathrm{~g}$ acid-detergent fibre (ADF) with $>900 \mathrm{~g}$ large particles (LP) (those retained on screens of aperture $3.35 \mathrm{~mm}$ and larger after wet-sieving (Dixon \& Milligan, 1985)). Cobalt mineralized salt blocks (Canadian Salt Ltd, Montreal) and water were available $a d$ lib.

\section{Preparation of the $\mathrm{Cr}$ mordanted particles}

The leafy material was first separated from the stems by hand. Half the stems were ground in a Wiley Mill grinder with a screen aperture of $2 \mathrm{~mm}$ (small particles; SP), and the other half were cut to $10 \mathrm{~mm}$ lengths (LP). The ground stems were then sieved by a wet-sieving procedure (Dixon \& Milligan, 1985) that allowed the particles to pass through a $2 \mathrm{~mm}$ screen but not through a $1 \mathrm{~mm}$ screen. Those passing were discarded. The particles retained by the $1 \mathrm{~mm}$ screen were kept and immersed in acetone for $24 \mathrm{~h}$, in methanol for $24 \mathrm{~h}$ to dissolve the cuticle, and then washed in boiling neutral detergent (Goering \& Van Soest, 1970). The stems were finally rinsed with distilled water.

The neutral-detergent-extracted bromegrass stems were mordanted with ${ }^{51} \mathrm{Cr}$-containing sodium dichromate by a modified technique (Uden et al. 1980) using 0.1 or $5 \mathrm{~g} \mathrm{Cr} / \mathrm{kg}$ fibre DM. The quantities of ${ }^{51} \mathrm{Cr}$ used were $10.9 \mathrm{mCi} / \mathrm{kg}$ fibre in the sodium dichromate solution for the LP and $41.7 \mathrm{mCi} / \mathrm{kg}$ fibre in the binding solution for the SP. The weight of sodium dichromate solution was four times that of the plant fibre and the heating time was $3 \mathrm{~h}$. The dry, mordanted stems were finally washed in boiling neutral detergent for $1 \mathrm{~h}$ and then washed thoroughly with tap-water until the solution was colourless. All the particles were then dried at $65^{\circ}$ for $24 \mathrm{~h}$, weighed, and the radioactivity/g DM was determined for each fraction using a gamma spectrometer (Model 8000; Beckman Instruments, Fullerton, California).

\section{Experimental design and schedule}

The experimental design was a $4 \times 4$ Latin square. The four treatments entailed $92 \mathrm{~g} \mathrm{LP}$ ( 10 $\mathrm{mm}) /$ animal or $24 \mathrm{~g} \mathrm{SP}(1-2 \mathrm{~mm}) /$ animal mordanted with either 5 or $0 \cdot 1 \mathrm{~g} \mathrm{Cr} / \mathrm{kg} \mathrm{DM}$. Equal quantities of particles were placed in six different locations: top and bottom of the reticulum, rumen ventral sac, rumen dorsal sac, and top and bottom of the caudal sac. The quantities added to the reticulo-rumen were $2.02 \times 10^{-3} \mathrm{~g} \mathrm{Cr}$ for low-level SP; $7.75 \times 10^{-3}$ $\mathrm{g}$ Cr for low-level LP; $8.21 \times 10^{-2} \mathrm{~g} \mathrm{Cr}$ for high-level SP; $3 \cdot 14 \times 10^{-1} \mathrm{~g} \mathrm{Cr}$ for high-level 
LP. The radioactivity of the material as put into the reticulo-rumen was $18-36 \times 10^{6}$ counts/minute $(\mathrm{cpm})$ depending on binding efficiency. After addition the reticulo-rumen contents were mixed by hand. The radioactive material was introduced into the reticulorumen at the beginning of each week for 4 weeks, and the sampling by hand from the same locations as particle additions commenced $2 \mathrm{~h}$ after each dosing. The first two were separated from the last two sampling weeks by 1 week to allow the radioactivity to decrease and rest the animals. Sampling was done at 2 and $4 \mathrm{~h}$, and then every $3 \mathrm{~h}$ for the following $57 \mathrm{~h}$, and every $6 \mathrm{~h}$ for the last $72 \mathrm{~h}$. Faeces were sampled from the rectum at the same times.

\section{Stability of $\mathrm{Cr}$ binding and digestibility of $\mathrm{Cr}$-bound particles}

Efficiency of ${ }^{51} \mathrm{Cr}$ binding was determined by measuring the proportion of total radioactivity associated with the stems after being exposed in the reaction mixture for various times. Stability of binding was estimated from the proportion of radioactivity lost from the stems in boiling neutral-detergent solution after different periods of heating. Digestibility of the mordanted particles was measured by the nylon-bag suspension in the rumen for $72 \mathrm{~h}$ (McQueen et al. 1980).

\section{Particle size determination}

The reticulo-rumen samples from the steers receiving the mordanted LP were sieved by the screen-by-screen wet-sieving method described by Dixon \& Milligan (1985) with the exception that the up and down cycle was repeated ten times before repeating the process for the next smaller screen. Screens of 7.74, 4.0 and $3.35 \mathrm{~mm}$ apertures were used to separate $\mathrm{LP}(>3.35 \mathrm{~mm})$ from SP $(<3.35 \mathrm{~mm}$ including microbial $\mathrm{DM})$. The rumen samples from the animals receiving the mordanted SP were sieved, but the faecal samples were not. All samples were dried at $65^{\circ}$ for at least $24 \mathrm{~h}$ before transfer to plastic vials for triplicate counting (Model 8000, gamma spectometer; Beckman Instruments).

Eating boluses were collected from the four steers by way of the rumen cannulas to verify by sieving the bolus LP and SP flows to the LP pool and SP pool respectively. The reticulorumen was emptied of its contents and the digesta were mixed and partly sieved to find the SP pool for the Grovum \& Williams' (1973) procedure.

\section{Calculations and statistical analysis}

Radioactivity (cpm) was converted to a per g DM basis and then transformed to natural logarithmic values. These values were plotted against time after dosing with ${ }^{51} \mathrm{Cr}$, and linear regression equations were calculated using SPSSX programs (Nie \& Hull, 1983). Univariate equations of type: $Y=$ intercept + slope $X$, were used to calculate the values for turnover time (TT), pool size $(A)$ and flow $(a)$ as described by Shipley \& Clark (1972) for a first-order kinetic pool. The analyses of variance for $T T, A$, and $a$ were conducted using an SPSSX program (Nie \& Hull, 1983). Subsequently, a quantitative reticulo-rumen model was developed for forage particles. The model values were determined as follows (Fig. 1).

(1) Feed intake: weight of feed DM intake;

(2) flow from the eating bolus to the LP pool: equal to flow $a$ for the LP (verified by sieving the bolus);

(3) flow from the eating bolus to the SP pool: (disappearance from SP pool)-(flow toward SP pool from LP pool), (verified by sieving the bolus);

(4) soluble component: (feed)-(flow to LP pool + flow to SP pool);

(5) LP pool size: $A$ for LP;

(6) SP pool size: $A^{1}$ for SP;

(7) disappearance from LP pool: $a$ of LP; 


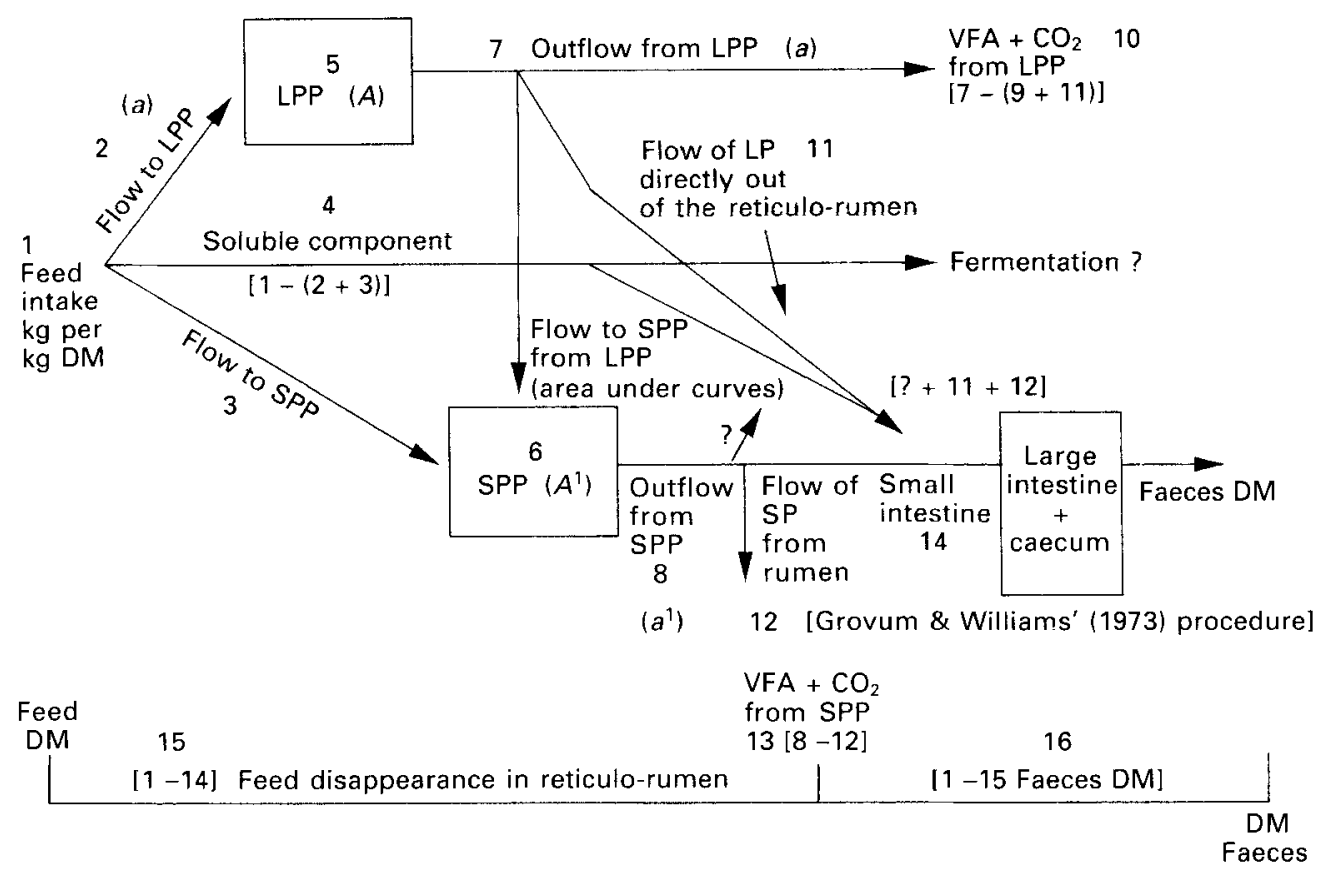

Fig. 1. Derivation of quantitative kinetic model of ruminant digestion of hay using ${ }^{51} \mathrm{Cr}$-mordanted bromegrass (Bromus inermis) stems. See p. 467 and below for key to nos. 1-18.

LPP, large particle (LP) pool: SPP, small particle (SP) pool; $A$, LPP size, VFA, volatile fatty acids; $A^{1}$, SPP size; $a$, slope originating from LP added; $a^{1}$, slope originating from SP added; $Y=$ in $\alpha_{0}-a x$;

$$
\alpha_{11}=\frac{A^{*}}{A}=\frac{\text { Total radioactivity (counts } / \mathrm{min} \text { ) given }}{\text { pool size }} \text {. }
$$

(8) disappearance from SP pool: $a^{1}$ of SP;

(9) flow toward SP pool from LP pool: obtained by comparing the area under the curve of the SP originating from LP to the area under the curve of LP disappearance;

(10) volatile fatty acids (VFA) $+\mathrm{CO}_{2}$ and methane from the LP pool: disappearance from LP pool -- (flow toward SP pool from LP pool + flow of LP directly out of the reticulorumen);

(11) flow of LP which go directly out of the reticulo-rumen : percentage of the total faecal DM weight formed by LP DM weight (obtained by wet sieving the faeces);

(12) outflow of the reticulo-rumen from the SP pool: obtained by Grovum \& Williams' (1973) procedure in animals dosed with SP;

(13) $\mathrm{VFA}+\mathrm{CO}_{2}$ and $\mathrm{CH}_{4}$ from the SP pool: disappearance of SP pool-outflow of reticulo-rumen from the SP pool;

(14) small intestine flow: (soluble component escaping rumen fermentation unknown $)+($ flow of LP which goes directly out of the reticulo-rumen) + (outflow of reticulorumen from SP pool);

(15) digestibility of $\mathrm{DM}$ in the reticulo-rumen: $\mathrm{DM}$-flow into small intestine (unknown);

(16) post-rumen digestibility: DM - (digestibility in rumen (unknown) and residual in faeces);

(17) total DM digestibility: DM feed-DM faeces;

(18) post-rumen TT: obtained by the procedure of Grovum \& Williams (1973). 


\section{Analytical technique}

Cell-wall contents were determined by the procedure of Goering \& Van Soest (1970) and $\mathrm{N}$ was determined by the Kjeldahl method (Association of Official Analytical Chemists, 1975).

\section{RESULTS AND DISCUSSION}

\section{Particle sieving technique}

Several authors have proposed that the particulate DM present in the rumen can be kinetically represented by two pools: an LP pool and an SP pool (Hungate, 1966; Poppi et al. 1981). Although Dixon \& Milligan (1985) demonstrated that there was no clearly discernible size below which all particles were equally eligible to leave the rumen, a two-pool model involving an SP and LP pool is likely to be a useful simplification in describing the kinetics of particulate matter in the rumen. Dixon \& Milligan (1985) concluded that for cattle, using the current sieving techniques, the DM retained by a $3.2 \mathrm{~mm}$ screen provided an appropriate minimum definition of the LP pool because fewer than $150 \mathrm{~g}$ faecal particles $/ \mathrm{kg}$ were of this size category.

The method of wet sieving used in the present study was described by Dixon \& Milligan (1985). The mechanical sieving techniques used in other studies where the orientation of particles and screens may be different (Jones \& Moseley, 1977; Poppi et al. 1980) could give different results. Consequently, differences in particle size distribution measured using different sieving techniques may, to a large extent, reflect differences in the basis of selectivity of the techniques, rather than actual particle size difference between experiments. For this reason comparisons of particle size distribution with other studies using different sieving techniques should be made with caution (Dixon \& Milligan, 1985).

\section{Stability test and digestibility}

The efficiency of binding $\mathrm{Cr}$ was inversely proportional to the concentration of $\mathrm{Cr}$ in the bathing solution (Table 1). This indicates that a limited number of sites are available for binding, or at least access to additional sites was increasingly difficult. The percentage of associated $\mathrm{Cr}$ subsequently lost from the stems in boiling neutral-detergent solution was also inversely proportional to the $\mathrm{Cr}$ concentration of the mordanting solution used (Table 1). With increased time-period of heating during mordanting there was increased extent and tenacity of binding (Table 1). This longer heating time-period might favour $\mathrm{Cr}$ binding to hydroxyl groups of components more resistant to degradation.

The digestibility of the LP and SP of NDF-extracted bromegrass stems was practically unaffected by mordanting with $0.1 \mathrm{~g} \mathrm{Cr} / \mathrm{kg} \mathrm{DM}$ (Table 2). The fibres mordanted with $5 \mathrm{~g}$ $\mathrm{Cr} / \mathrm{kg} \mathrm{DM}$ had their digestibility substantially reduced. This is in agreement with Uden et al. (1980), who stated that when the concentration of $\mathrm{Cr}$ on mordanted particles was increased (from 0 to $80 \mathrm{mg} / \mathrm{g} \mathrm{DM}$ ) the in vitro cell wall digestibility decreased drastically.

The loss of ${ }^{51} \mathrm{Cr}$ during rumen incubation was nearly identical to the loss of DM (Table 1). Thus, the label appears to be associated with components of the extracted particles that are removed during digestion. Nevertheless, the fate of $\mathrm{Cr}$ liberated by digestion is unknown. One might expect that the $\mathrm{Cr}$ would remain bound to very small particles because of the strong hexacoordinate ligands formed with hydroxyl groups during mordanting (Uden et al. 1980). Ellis et al. (1980) stated that feedstuffs mordanted with $\mathrm{Cr}$ constitute labelled material in which there is little doubt as to marker location because migration within and between particles is low. 
Table 1. Binding of chromium to neutral-detergent-extracted bromegrass (Bromus inermis) stems as influenced by $\mathrm{Cr}$ concentration during mordanting*

(Mean values with their standard errors)

\begin{tabular}{|c|c|c|c|c|c|c|c|}
\hline & \multirow{3}{*}{$\begin{array}{l}\text { Cr concentration } \\
\text { for mordanting } \\
\text { ( } \mathrm{g} \mathrm{Cr} / \mathrm{kg} \text { stems) }\end{array}$} & \multicolumn{6}{|c|}{ Period of heating (h) } \\
\hline & & \multicolumn{2}{|c|}{1} & \multicolumn{2}{|c|}{3} & \multicolumn{2}{|c|}{24} \\
\hline & & Mean & $\mathrm{SE}$ & Mean & $\mathrm{SE}$ & Mcan & $\mathrm{SE}$ \\
\hline $\begin{array}{l}\text { Proportion of added }{ }^{51} \mathrm{Cr} \text { bound } \\
\text { to stems }(\times 100)\end{array}$ & $\begin{array}{c}100 \\
20 \\
15 \\
10 \\
5 \cdot 0 \\
0 \cdot 1\end{array}$ & $\begin{array}{l}17 \cdot 8 \\
27 \cdot 8 \\
27 \cdot 0 \\
29 \cdot 9 \\
36 \cdot 8 \\
51 \cdot 2\end{array}$ & $\begin{array}{l}2 \cdot 7 \\
4 \cdot 4 \\
4 \cdot 3 \\
5 \cdot 9 \\
7 \cdot 4 \\
9 \cdot 5\end{array}$ & $\begin{array}{l}35 \cdot 5 \\
47 \cdot 1 \\
48 \cdot 3 \\
53 \cdot 9 \\
68 \cdot 4 \\
84 \cdot 2\end{array}$ & $\begin{array}{r}5.8 \\
7.0 \\
7.2 \\
8.6 \\
12.3 \\
15.8\end{array}$ & $\begin{array}{l}70 \cdot 4 \\
72 \cdot 6 \\
82 \cdot 8 \\
88 \cdot 9 \\
90 \cdot 1 \\
91 \cdot 0\end{array}$ & $\begin{array}{r}6.9 \\
10 \cdot 8 \\
7 \cdot 9 \\
13 \cdot 3 \\
12 \cdot 4 \\
14.0\end{array}$ \\
\hline $\begin{array}{l}\text { Proportion of stem }{ }^{51} \mathrm{Cr} \text { removed by } \\
\text { boiling neutral detergent }(\times 100)\end{array}$ & $\begin{array}{c}100 \\
20 \\
15 \\
10 \\
5.0 \\
0.1\end{array}$ & $\begin{array}{l}14 \cdot 1 \\
26 \cdot 8 \\
24 \cdot 8 \\
26 \cdot 8 \\
38 \cdot 5 \\
37 \cdot 1\end{array}$ & $\begin{array}{l}1 \cdot 3 \\
1 \cdot 9 \\
2 \cdot 6 \\
2 \cdot 2 \\
3 \cdot 1 \\
3 \cdot 4\end{array}$ & $\begin{array}{r}8 \cdot 4 \\
14 \cdot 2 \\
14 \cdot 1 \\
14 \cdot 6 \\
24 \cdot 4 \\
28 \cdot 6\end{array}$ & $\begin{array}{l}0 \cdot 9 \\
1 \cdot 1 \\
1 \cdot 3 \\
1.7 \\
2 \cdot 1 \\
2 \cdot 6\end{array}$ & $\begin{array}{r}6 \cdot 8 \\
12.5 \\
11 \cdot 5 \\
10 \cdot 6 \\
16.9 \\
29 \cdot 9\end{array}$ & $\begin{array}{l}0.5 \\
1.3 \\
0.5 \\
0.9 \\
1.4 \\
2.3\end{array}$ \\
\hline
\end{tabular}

* For details of procedures, see pp. 466467.

Table 2. In situ rumen digestibility $(72 h)$ of non-mordanted and chromium-mordanted particles of neutral-detergent-extracted bromegrass (Bromus inermis) stems*

(Mean values with their standard errors)

\begin{tabular}{|c|c|c|c|c|c|}
\hline \multirow{2}{*}{$\begin{array}{l}\text { Size of } \\
\text { particles } \\
(\mathrm{mm})\end{array}$} & \multirow[b]{2}{*}{ Cr level (g/kg DM) } & \multicolumn{2}{|c|}{ DM digestibility } & \multicolumn{2}{|c|}{ Loss of ${ }^{51} \mathrm{Cr}$} \\
\hline & & Mean & $\mathrm{SE}$ & Mean & $\mathrm{SE}$ \\
\hline \multirow[t]{3}{*}{10} & 0 & $0-31$ & 0.02 & & \\
\hline & $0 \cdot 1$ & $0 \cdot 24$ & 0.02 & $0 \cdot 34$ & 0.06 \\
\hline & $5 \cdot 0$ & $0 \cdot 20$ & 0.08 & $0 \cdot 22$ & $0 \cdot 07$ \\
\hline \multirow[t]{3}{*}{$1-2$} & 0 & $0 \cdot 50$ & 0.03 & & \\
\hline & $0 \cdot 1$ & 0.48 & 0.08 & $0 \cdot 50$ & $0 \cdot 06$ \\
\hline & $5 \cdot 0$ & $0 \cdot 32$ & 0.06 & $0 \cdot 33$ & $0-08$ \\
\hline
\end{tabular}

* For details of procedures, see pp. 466-467.

Kinetic regression equations based on rumen sampling

The high $R^{2}$ values (Table 3 ) indicate that LP and SP pools in the rumen were reasonably represented as homogenous first-order kinetic pools. This is in agreement with experiments (Dixon \& Milligan, 1985) in which disappearance from the rumen of fluid, particulate, and microbial markers, occurs according to first-order kinetics The better fit of SP than LP probably reflects the fact that more particles were introduced into the rumen in the small form and, therefore, sampling would entail less statistical variation. Also, mixing of SP is likely to occur more rapidly than for LP. The marker disappearance slopes and turnover times were not significantly different $(P>0.05)$ between SP and LP, whether mordanted with 5 or $0.1 \mathrm{~g} \mathrm{Cr} / \mathrm{kg} \mathrm{DM}$, and animal differences explained the majority of the variations 


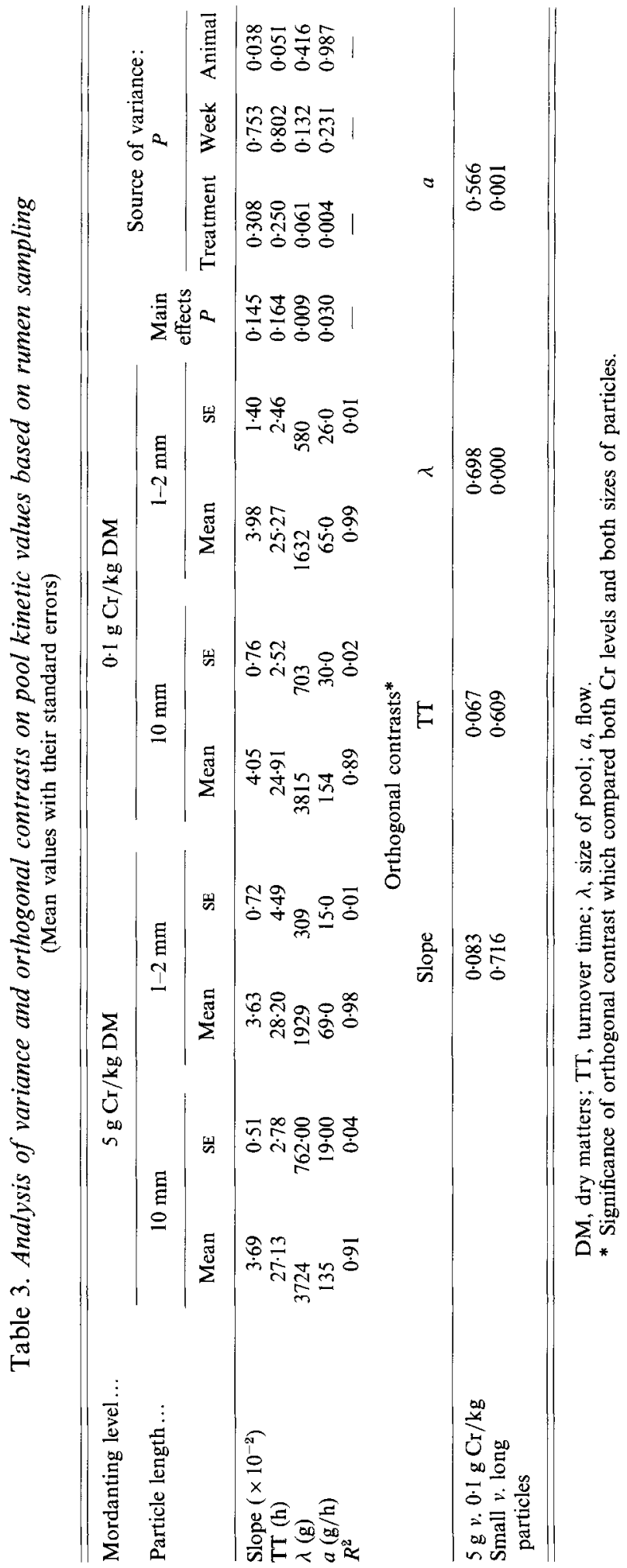




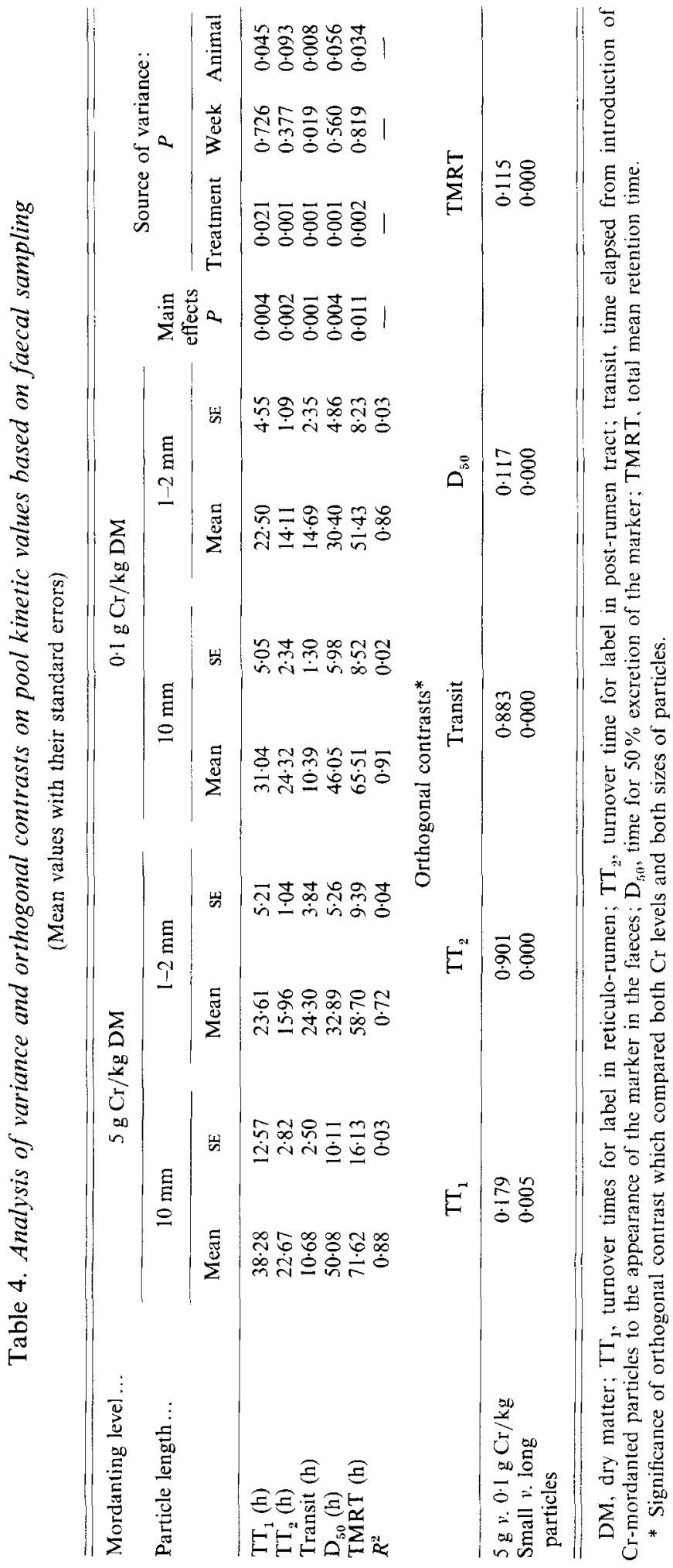


between these treatments $(P<0 \cdot 05)$. The LP pool size $(A)$ was significantly greater than the SP pool size $\left(A^{1}, P<0.001\right)$. The disappearances from each pool ( $a$ and $\left.a^{1}\right)$ were different $(P<0.01)$, with the LP pool flow being greater $(P<0.05)$ than the SP pool flow.

Particle sizes and $\mathrm{Cr}$ concentrations were used in the treatments, consequently orthogonal contrasts (Table 3) were necessary to separate the effects of these two factors on the pool kinetic variables. The TT differences tended to depend on $\mathrm{Cr}$ concentrations $(P<0 \cdot 10)$, while pool sizes and flows were related to particle size $(P<0.001)$. The shorter TT of the particles treated with $0 \cdot 1 \mathrm{~g} \mathrm{Cr} / \mathrm{kg}$ DM than those treated with $5 \mathrm{~g} \mathrm{Cr} / \mathrm{kg} \mathrm{DM}$ may reflect the greater digestibility of the former preparation. The size of, and flow of DM through, the kinetic pool of LP were roughly twice as great as for SP. Therefore, the values for TT of SP and LP pools were nearly equal. These observations are consistent with results of Dixon \& Milligan (1985), who found that the LP pool was about 600 (sE 70) $\mathrm{g} / \mathrm{kg}$ and the SP pool was 400 (SE 50) $\mathrm{g} / \mathrm{kg}$ of the total rumen particle pool for steers given long hay.

The fractional turnover rate of the ${ }^{51} \mathrm{Cr}$-labelled material in the LP pool itself would be equal to the sum of the rate-constants of the digestion of LP DM and the mechanical breakdown of the LP to SP, plus the small proportion of LP which passes directly out of the reticulo-rumen. These combined processes for our cattle given a diet of chopped hay sum to a daily turnover rate of 0.88 (SE 0.09) for high $\mathrm{Cr}$ particles and 0.96 (SE 0.1) for low $\mathrm{Cr}$ particles. These values agree with the observations of Dixon \& Milligan (1985) who measured a rumen LP pool fractional turnover rate of $0.82 / \mathrm{d}$ for steers given chopped hay.

The daily turnover rate of the SP pool was $0.85(\mathrm{SE} 0 \cdot 16) / \mathrm{d}$ for the high-Cr particles and 0.95 (SE 0.1)/d for the low-Cr particles. These results are consistent with those of Dixon \& Milligan (1985) who observed that the fractional outflow rate (FOR) of lignin in the rumen SP pool was $1 \cdot 07 / \mathrm{d}$. This was similar to the mean FOR $(1 \cdot 17 / \mathrm{d})$ of the $2 \cdot 0-3 \cdot 2,1 \cdot 0-2 \cdot 0$ and 0.25-0.5 mm mesh particle groups (Dixon \& Milligan, 1985).

\section{Rate constants derived from the changes in concentrations of marker in the faeces}

TT for label in the reticulo-rumen $\left(\mathrm{TT}_{1}\right)$ and the post-rumen tract $\left(\mathrm{TT}_{2}\right)$, time-interval for $500 \mathrm{~g} / \mathrm{kg}$ excretion of the marker $\left(D_{50}\right)$ and total mean retention time (TMRT) were all significantly affected $(P<0.05)$ by particle size, but not by level of $\mathrm{Cr}$ treatment (Table 4$)$.

$\mathrm{TT}_{1}$ of SP was 23.6 (SE 4.4) $\mathrm{h}$ and 22.5 (SE 2.5) $\mathrm{h}$ for high-Cr and low-Cr markers respectively. However, $\mathrm{TT}_{1}$ of LP as determined from faecal sampling (38.3 (SE 12.6) h high$\mathrm{Cr}, 31.0(\mathrm{SE} 5 \cdot 1) \mathrm{h}$ low-Cr) was greater $(P<0.05)$ than the TT of LP calculated from rumen sampling (27.1 (SE 2.78) h high $\mathrm{Cr}, 24.9$ (SE 2.5) h low-Cr). The faecal sampling technique, however, yields the TT of overall LP flow, including both the reticulo-rumen breakdown and digestion of LP, plus passage of the resulting SP. A rate-limiting step when clearing dietary residues from the reticulo-rumen is passage through the reticulo-omasal orifice (Ulyatt et al. 1986). Since particle size reduction is virtually a prerequisite for passage through this orifice (Evans et al. 1973; Ulyatt et al. 1976; Welch \& Smith, 1978; Poppi et al. 1981), it is important to realize that the undigested component of the LP pool has a TT for the total reticulo-rumen, determined by the time-interval for breakdown of the LP pool plus time for passage through the SP pool.

Calculation of TT from the descending phase of label in faecal SP following rumen administration of labelled LP yielded an average value of 47 (SE 8 ) h. Addition of the rumen TT of LP plus the rumen TT of SP yielded an average of 51 (SE 5) h. Across individual trials, the descending phase TT and sum of rumen turnover were correlated, with a regression coefficient of 0.82 . Thus, calculation of TT from the SP in the descending phase appears to relate more closely to digestive events than did calculation of TT of the LP from rumen sampling (31-38 h).

The direct passage of LP from the rumen would speed up the reticulo-rumen TT of LP 
determined by rumen sampling. It would also speed up reticulo-rumen TT determined from faecal sampling.

The size of the reticulo-rumen particles influenced $(P<0.01)$ the estimate of $\mathrm{TT}_{2}$ (Table 4). Label from the LP passed more slowly through the hind-gut. This may have been due to LP which passed directly out of the rumen.

The concentration of $\mathrm{Cr}$, and consequently a change in the digestibility of the particles, did not appear to have any significant effect on the TT, $\mathrm{D}_{50}$ or TMRT (Table 4). On the other hand, the latter three values were greater $(P<0.01)$ for LP than for SP. This is in agreement with Van Soest (1982), who stated that particle size per se tends to have its own effect on passage, with SP passing faster than LP.

There is relatively no breakdown of LP in the post-ruminal tract. The breakdown of LP is dependent on four main factors: chewing during eating, chewing during rumination, microbial degradation and detrition. The most important factors are the first two, the last two factors having relatively very little influence (Ulyatt et al. 1986). Some authors such as Grenet (1970), Poppi et al. (1980), Uden \& Van Soest (1982) have stated that there is very limited breakdown of LP in the post-ruminal tract despite the fact that there is considerable fermentation in the caecum and proximal colon (Ulyatt et al. 1975).

There were important variations between animals which gave rise to large standard errors. While the disappearance TT for SP was apparently smaller than TT for the outflow of residual SP, they were not significantly different (Tables 3 and 4). The SP pool was calculated twice, once for TT disappearance (first-order kinetics) where the SP pool was $A^{1}$, and a second time where the rumen content was emptied and partly sieved to find the SP pool with the Grovum \& Williams' (1973) procedure. This last SP pool was slightly smaller than the first one, but not significantly different. This SP pool was used to calculate outflow from the SP pool in the model. This is why TT of the SP pool in the first-order kinetic calculations is larger than TT $^{1}$ in the Grovum \& Williams' (1973) procedure and does not implicate a larger outflow of residual SP than disappearance of SP from the SP pool.

\section{Quantitative model $(0 \cdot 1 \mathrm{~g} \mathrm{Cr} / \mathrm{kg} \mathrm{DM})$}

A kinetic model using values derived from the particles subjected to low-level $\mathrm{Cr}$ mordanting is presented in Fig. 2. Some $20 \%$ of the DM of the eating bolus was soluble. DM flow to the LP pool accounted for 680 (SE 150) g/ $/ \mathrm{kg}$ total DM or 850 (SE 190) $\mathrm{g} / \mathrm{kg}$ particulate DM of the eating bolus. The DM flow directly to the SP pool was 120 (SE 30) $\mathrm{g} / \mathrm{kg}$ total DM or $150(\mathrm{SE} 60) \mathrm{g} / \mathrm{kg}$ bolus particulate DM. The finding that DM of the eating bolus was composed $(/ \mathrm{kg})$ of $800 \mathrm{~g}$ in particles and $200 \mathrm{~g}$ in soluble form when the hay contained more than $900 \mathrm{~g} / \mathrm{kg} \mathrm{DM}$ in LP, is in agreement with Ulyatt et al. (1986) who stated that approximately $350 \mathrm{~g} / \mathrm{kg} \mathrm{DM}$ of fresh forage are solubilized by chewing, while only $200-300 \mathrm{~g} / \mathrm{kg}$ are solubilized from dried diets. There are large quantitative differences in the results of experiments measuring the particle sizes of eating boluses in the literature; many of these can be explained in terms of the sieving techniques used (Ulyatt et al. 1986). Nevertheless, chewing during eating is efficient in releasing the soluble components. Firstorder kinetic calculations indicated that the LP pool was 3.82 (SE 0.47) kg and the SP pool was 1.63 (SE 0.18$) \mathrm{kg}$, or 0.70 and 0.11 of the particulate DM in the rumen. When samples of rumen contents were wet-sieved, 650 (SE 50) $\mathrm{g} / \mathrm{kg}$ and 330 (SE 30) $\mathrm{g} / \mathrm{kg}$ particulate DM were measured to be in LP and SP respectively. Thus, the calculated values were in general overall agreement with the sieving-technique results.

The breakdown of large particles to small particles depends on four main factors: chewing during eating, chewing during rumination, microbial degradation and detrition. The two first factors are the most important (Ulyatt et al. 1986). The bolus sieving in the present paper concerns only one of these factors which is chewing during eating. Three 


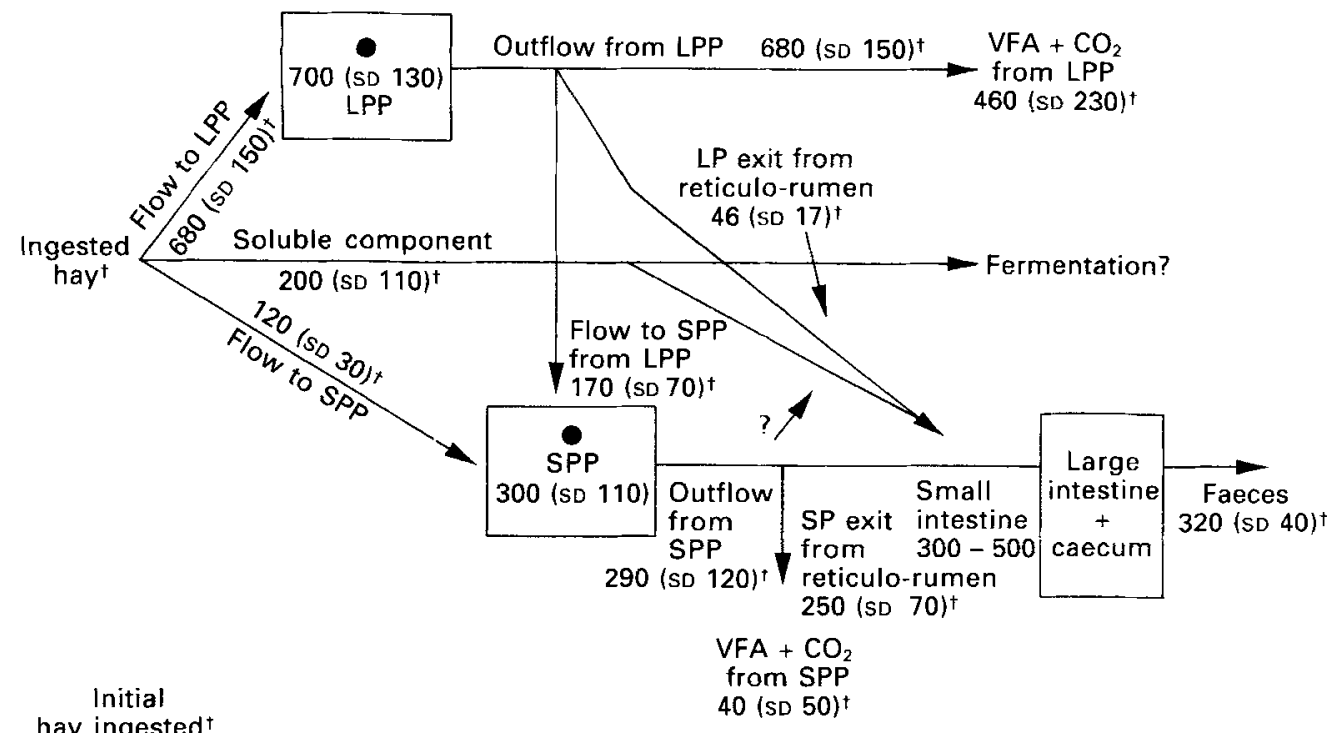

hay ingested ${ }^{\dagger}$

Reticulo-rumen digestion $500-700^{\dagger}$

Lower tract digestion $0-180^{\dagger}$

Undigested $320(\text { SD } 40)^{\dagger}$

Fig. 2. Quantitative kinetic model of ruminant digestion of hay using bromegrass (Bromus inermis) stems mordanted with a low level of ${ }^{51} \mathrm{Cr}(0 \cdot 1 \mathrm{~g} \mathrm{Cr} / \mathrm{kg}$ fibre dry matter (DM)). Proportion of total particulate $\mathrm{DM}$ in the reticulo-rumen (O). Large particle (LP) pool (LPP); small particle (SP) pool (SPP); VFA, volatile fatty acids. $\dagger$ Values are $\mathrm{g} / \mathrm{kg}$ hay DM ingested.

results are seen from chewing during eating: long forages are reduced to a size that can be incorporated into a bolus and swallowed; soluble nutrients, especially from fresh forages, are released for fermentation; and the inner structures of forage material are exposed to enable effective invasion of the ruminal microbes. Rumination serves two purposes: it damages regurgitated digesta to expose internal plant structures further for microbial attack, and it reduces the particle size of refractory material (Ulyatt $e t$ al. 1986). In this model, which is a simplification of the numerous digestion processes, only the original flow from feed (eating bolus) to the two pools (LP and SP) is considered. Rumination will influence the model by affecting the marker kinetics from the pools $\left(a, a^{1}\right)$.

Disappearance of DM from the LP pool consisted of production of VFA, $\mathrm{CO}_{2}$ and $\mathrm{CH}_{4}$ (460 (SE 230) g/ kg original feed DM), LP which go directly out of the reticulo-rumen (46 (SE 17) $\mathrm{g} / \mathrm{kg}$ ), and LP which go to the SP pool (170 (SE 70) g/kg). Thus, fermentation products accounted for $0.68 \mathrm{DM}$ disappearance from the LP pool. Flow from the LP pool constituted 0.59 of flow into the SP pool. Flow of large particles directly out of the reticulorumen was relatively small $(0.07$ of the DM flow out of the LP pool), which is in agreement with Dixon \& Milligan (1985). These authors noted that only $0.11-0.15$ of the faecal particulate DM was retained by $3.2 \mathrm{~mm}$ mesh and larger screens. This was in agreement with our observation that $0 \cdot 16$ (SE 0.06) of the particulate DM in the faeces was in LP $(>3.2 \mathrm{~mm})$.

The present values do not yield an estimate of VFA, $\mathrm{CO}_{2}$ and $\mathrm{CH}_{4}$ produced by the fermentation of the soluble components. However, one might expect that some part of the soluble components originating from the eating bolus may pass readily out of the reticulorumen and be absorbed in the lower digestive tract. Van Soest (1982) stated that fine, soluble and liquid matter escape the rumen more rapidly than coarse, light, solid matter, 
although Dixon \& Milligan (1985) noted that the FOR of even the smaller rumen particle groups is considerably less than that of water. However, for materials that are passed rapidly, time of fermentation may limit the extent of digestion in the rumen (Owen \& Goetsch, 1986). Some of the soluble fraction would also be assimilated by rumen microbes and pass through the reticulo-omasal orifice in this form.

There is a significant difference between the model where $60-70 \%$ of the disappearance of LP from the LP pool was by digestion and the much smaller losses occurring during the $72 \mathrm{~h}$ incubation in nylon bags. Breakdown and digestion of particles are influenced by many factors: breakdown by chewing eating, chewing rumination, microbial degradation, and detrition. In nylon bags only the two last factors have an influence. Breakdown by chewing in both eating and rumination is a very important factor for microbial digestion by facilitating access of bacteria to internal structures and dissolving the DM. Microbes cannot easily penetrate the undamaged epidermis of plant material except via stomata (Cheng et al. 1980). The overall effect of chewing during eating and rumination on digestion has been studied by comparing the digestion of a chewed diet with that of the unchewed material. Bailey \& Balch (1961) avoided chewing during eating by feeding cows via a rumen fistula: rumination time increased from 430 to $630 \mathrm{~min} / \mathrm{d}$. Bailey (1962) also found a greater rate of digestion of DM, fibre, protein and ash in chewed grass than in unchewed grass when they were digested in the rumen in nylon bags. Similarly, Poppi et al. (1981) showed not only that the rate of digestion of tropical grasses in nylon bags was faster for chewed $(0.022 / \mathrm{h})$ than unchewed $(0.016 / \mathrm{h})$ leaf and stem fractions, but also that lag time before significant digestion occurred was considerably greater in unchewed $(15.5 \mathrm{~h})$ than in chewed material $(3 \cdot 1 \mathrm{~h})$. A. John (unpublished results) found a similar effect using fresh ryegrass and fescue; the initial rate of DM digestion in nylon bags was $105 \%$ greater in chewed grass than in the same material unchewed. In this model technique the mordanted particles were not in nylon bags. Thus the three last factors influencing breakdown of particles were acting on the LP and the SP. The relatively small amount of mordanted particles added to the rumen were available for chewing during rumination and so had their epidermis damaged during this chewing. Also, to some extent, to put NDF particles bound with $\mathrm{Cr}$ directly into the rumen mimics the entry of natural particles into the reticulo-rumen after the washing process of chewing during eating where considerable soluble materials are washed into the saliva.

The DM disappearance from the SP pool included formation of VFA, $\mathrm{CO}_{2}$ and $\mathrm{CH}_{4}(40$ (SE 50) g/ $\mathrm{kg}$ original feed DM or 140 (SE 170) g/ $\mathrm{kg}$ total DM from this pool) and outflow from the rumen (250 (SE 70) g/ kg original feed or 860 (SE 240) g/ $\mathrm{kg}$ total DM of this pool). The quantities of VFA plus $\mathrm{CO}_{2}$ produced in this way are relatively small, but this is logical because about 0.60 of the SP pool originates from the LP pool, and consequently has already been subjected to fermentation. On the other hand, it could be expected that the intensity of microbial attack on the small particles would be greater due to a larger surface per unit weight. Nevertheless, Pond et al. (1984) stated that simple reduction in particle size does not mean the material will be more digestible, or that the rate of digestion will be greater. Akin \& Burdick (1981) found that many small forage particles were deeply stained with acid phloroglucinol, indicating a high content of lignin and low digestibility, in which case no increase in digestibility would be predicted from further particle size reduction or increased surface area exposure.

According to the kinetic calculation of the present study, material leaving the reticulorumen consisted of LP, SP and soluble components that were equivalent to $0 \cdot 07,0.25$ and 0.20 of original feed DM. These results are consistent with the idea that the relative resistance of DM to passage is related to size (Poppi et al. 1980; Weston \& Cantle, 1984). Clearance rate within diets approaches zero for the largest particle fraction and progressively increases as the size of particles decreases (Weston \& Kennedy, 1984). 


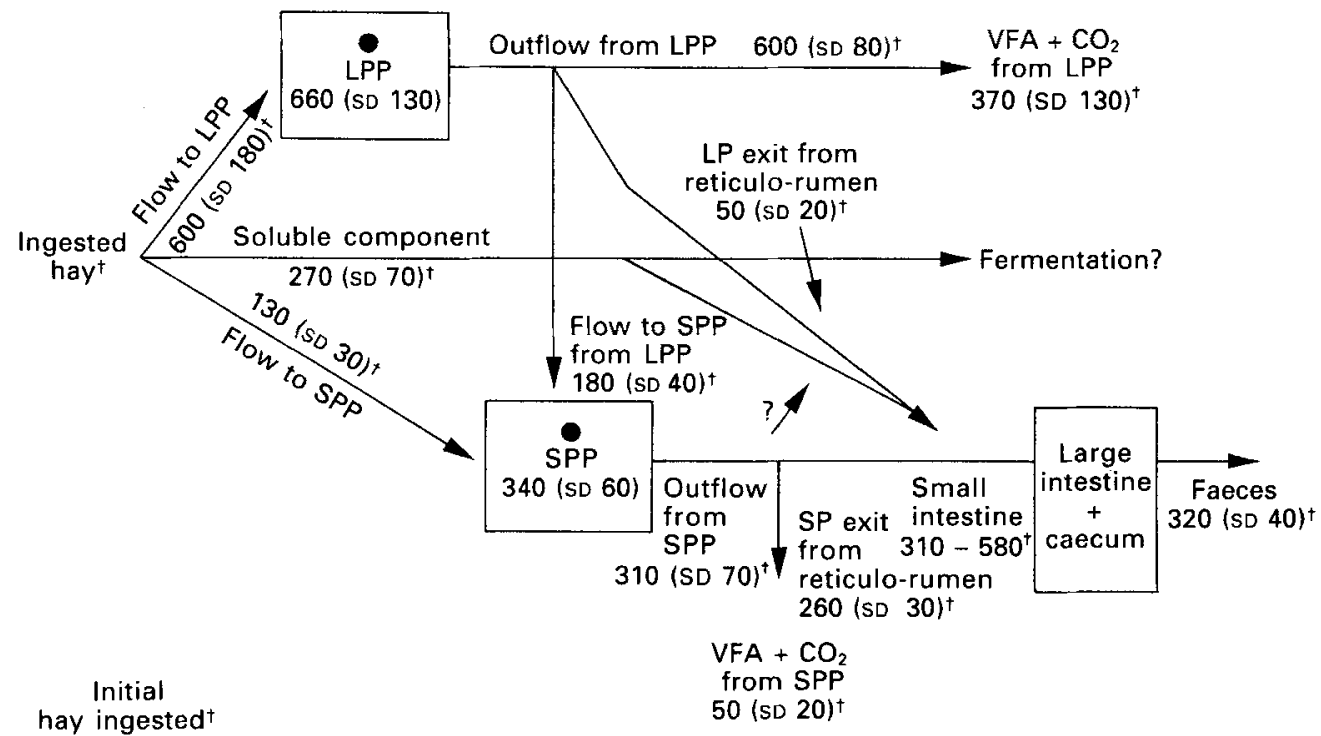

Reticulo-rumen digestion $420-690^{\dagger}$

Lower tract digestion $0-260^{\dagger}$

Undigested $320(S D 40)^{\dagger}$

Fig. 3. Quantitative kinetic model of ruminant digestion of hay using bromegrass (Bromus inermis) stems mordanted with $5 \mathrm{~g}{ }^{51} \mathrm{Cr} / \mathrm{kg}$ fibre dry matter (DM). Proportion of total particle DM in the reticulo-rumen (O). Large particle (LP) pool (LPP); small particle (SP) pool (SPP); VFA, volatile fatty acids. † Values are $\mathrm{g} / \mathrm{kg}$ hay DM ingestel.

The apparent DM digestibility of the hay was 684 (SE 38) $\mathrm{g} / \mathrm{kg}$, of which $0.74-1.00$ (depending on the site of digestion of soluble components) occurred in the reticulo-rumen. Previously, the proportion of the total digestible organic matter digested in the rumen in cattle given forage diets has been estimated as $0.71-0.82$ for oaten chaff (Redman et al. 1980), 0.79 for wheaten straw (Sriskandarajah et al. 1982), 0.82-0.89 for spear grass hay (Hunter \& Sieberg, 1980) and 0.80 0.93 for mixed grass and legume hay (Kennedy, 1982).

\section{Comparison between models using results from low-Cr and high-Cr markers}

Comparison of kinetic models (Figs. 2 and 3) for the two concentrations reveals that there was a greater proportion of soluble components, less LP, and the same proportion of SP in the high-Cr model compared with the low-Cr model. On the other hand, the SP pool was larger. Less VFA plus $\mathrm{CO}_{2}$ and $\mathrm{CH}_{4}$ were produced from the LP pool. The LP which go directly out of the reticulo-rumen and the flow toward the SP pool from the LP pool were both increased in the high-Cr model. Disappearance from the SP poo, and outflow of the rumen from the SP pool were similar between the two concentrations as well as the VFA plus $\mathrm{CO}_{2}$ and $\mathrm{CH}_{4}$ production from the SP pool. The VFA and $\mathrm{CO}_{2}$ and $\mathrm{CH}_{4}$ produced from the LP pool were less for the $5 \mathrm{~g} \mathrm{Cr} / \mathrm{kg} \mathrm{DM}$ model. The main differences between the two models appeared to be a consequence of lower digestibility of particles containing the higher level of $\mathrm{Cr}$, and underscore marker effects on values obtained. The other kinetic values seem to be relatively similar within the relatively large standard deviations.

Large standard deviations indicate differences between animals in particle size reduction by chewing during eating. This was also found by Ulyatt et al. (1986) who stated that there are consistent differences between animals in the effectiveness of chewing.

Formation of fermentation products (VFA, $\mathrm{CO}_{2}, \mathrm{CH}_{4}$ ) in the reticulo-rumen accounted for 0.72 (low-Cr markers) to 0.61 (high-Cr markers) of the total feed DM digested. This is 
supported by Sutton (1972) who stated that production of VFA in the rumen fermentation provides between 500 and $700 \mathrm{~g} / \mathrm{kg}$ of the total digestible energy.

This model is a simplification of the multiple digestive processes acting in the ruminant animal. The technique yields quantitative understanding of different digestive functions. Nevertheless, more work remains to be done to improve the actual descriptive field which was limited to NDF extracted bromegrass stems.

Support of this study by the Agricultural Research Council of Alberta and the Natural Sciences and Engineering Research Council of Canada is acknowledged.

\section{REFERENCES}

Akin, D. E. \& Burdick, D. (1981). Relationships of different histochemical types of lignified cell walls to forage digestibility. Crop Science 21, 577-581.

Association of Official Analytical Chemists (1975). Official Methods of Analysis, 12th ed. Washington, DC: AOAC.

Bailey, C. B. (1962). Rates of digestion of swallowed and unswallowed dried grass in the rumen. Canadian Journal of Animal Science 42, 49-54.

Bailey, C. B. \& Balch, C. C. (1961). The digestion of hay administered to cows through rumen fistulas. British Journal of Nutrition 15, 183-188.

Cheng, K. J., Fay, J. P., Howarth, R. E. \& Costerton, J. W. (1980). Sequence of events in the digestion of fresh legume leaves by rumen bacteria. Applied and Environmental Microbiology 40, 613-625.

Church, D. C. [editor] (1979). Digestive Physiology and Nutrition of Ruminamts, 2nd ed. pp. 99-104. Portland, Oregon: O \& B Books, Inc.

Colucci, P. E. (1979). Rate of passage of digesta through the gastrointestinal tract in dairy cattle. MSc Thesis, Cornell University, Ithaca, NY.

Dixon, R. M. \& Milligan, L. P. (185). Removal of digesta components from the rumen of steers determined by sieving techniques and fluid, particulate and microbial markers. British Journal of Nutrition 53, 347-362.

Ehle, F. R. (1984). Influence of feed particle density on particulate passage from rumen of Holstein cow. Journal of Dairy Science 67, 693-699.

Ellis, W. C., Lascano, C., Teeter, R. G. \& Owens, F. N. (1980). Solute and particle flow markers. In Protein Requirements for Cattle: A Symposium. Oklahoma State University Publication no. MP109, pp, 37-56 [F, N. Owen, editor]. Stillwater, Oklahoma: Oklahoma State University.

Evans, E. W., Pearce, G. G., Burnett, I. \& Pillinger, S. L. (1973). Changes in some physical characteristics of the digesta in the reticulo-rumen of cows fed once daily. British Journal of Nutrition 29, 357-376.

Faichney, G. J. (1986). The kinetics of particulate matter in the rumen. In Control of Digestion and Metabolism in Ruminants, pp. 173-195 [L. P. Milligan, W. L. Grovum and A. Dobson, editors]. Englewood Cliffs, New Jersey: Prentice-Hall.

Goering, H. K. \& Van Soest, P. J. (1970). Forage fiber analyses (apparatus, reagents, procedures and some applications). United States Department of Agriculture, Agriculture Handbook no. 379. Washington, DC: US Department of Agriculture

Grenet, E. (1970). Taille et structure des particules végétales au niveau du feuillet et des fèces chez les bovins. Annales de Biologie Animale, Biochimie, Biophysique 10, 643-657.

Grovum, W. L. \& Williams, V. J. (1973). Rate of passage of digesta in sheep. Passage of marker through the alimentary tract and biological relevance of rate-constants derived from the changes in concentration of marker in faeces. British Journal of Nutrition 30, 313-329.

Hungate, R. E. (1966). The Rumen and its Microbes. New York: Academic Press.

Hunter, R. A. \& Sieberg, B. D. (1980). The utilization of spear grass (Heteropogon contortus) IV. The nature and flow of digesta in cattle fed on spear grass alone and with protein or nitrogen or sulfur. Australian Journal of Agricultural Research 31, 1037-1047.

Jones, J. R. \& Moseley, G. (1977). A wet sieving technique for estimating particle size distribution in sheep digesta. Laboratory Practice 26, 687-689.

Kennedy, P. M. (1982). Ruminal and intestinal digestion in Brahman crossbred and Hereford cattle fed alfalfa or tropical pasture hay. Journal of Animal Science 55, 1190-1199.

McQueen, R. E., Bush, R. S. \& Nicholson, J. W. G. (1980), Variability of forage digestion in nylon bags suspended in the rumen. Canadian Journal of Animal Science 60, 1038.

Nie, N. H. \& Hull, C. H. (1983). SPSSX. Chicago, Ill.: McGraw-Hill Book Co.

Owen, F. N. \& Goetsch, A. L. (1986). Digesta passage and microbial protein synthesis. In Control of Digestion and Metabolism in Ruminants, pp. 196-223 [L. P. Milligan, W. L. Grovum and A. Dobson, editors]. Englewood Cliffs, New Jersey: Prentice-Hall.

Pond, K. R., Ellis, W. C. \& Akin, D. E. (1984). Ingestive mastication and fragmentation of forages. Journal of Animal Science 58, 1567. 
Poppi, D. P., Minson, D. J. \& Ternouth, J. H. (1981). Studies in cattle and sheep eating leaf and stem fractions of grasses. 3. The retention time in the rumen of large feed particles. Australian Journal of Agricultural Research 32, 123-127.

Poppi, D. P., Norton, B. W., Minson, D. J. \& Hendrickson, R. E. (1980). The validity of the critical size theory for the particles leaving the rumen. Journal of Agricultural Science, Cambridge 94, 275-280.

Redman, R. G., Kellaway, R. C. \& Leibholz, J. (1980). Utilization of low quality roughages: effects of urea and protein supplements of differing solubility on digesta flows, intake and growth rate of cattle eating oaten chaff. British Journal of Nutrition 44, 343-354.

Shipley, R. A. \& Clark, R. E. (1972). Tracer Methods for in vivo Kinetics: Theory and Applications. New York and London: Academic Press.

Sriskandarajah, N, Kellaway, R. C. \& Leibholz, J. (1982). Utilization of low quality roughages: effects of supplementing with casein treated or untreated with formaldehyde on digesta flows, intake and growth rate of cattle eating wheat straw. British Journal of Nutrition 47, 553-563.

Sutton, J. D. (1972). In vivo measurement of energy supply and protein synthesis in the rumen. In Tracer Studies on Non-protein Nitrogen for Ruminants, pp. 35-42. Vienna: International Atomic Energy Agency.

Uden, P., Colucci, P. E. \& Van Soest, P. J. (1980). Investigation of chromium, cerium and cobalt as markers in digesta rate of passage studies. Journal of the Science of Food and Agriculture 31, 625-632.

Uden, P. \& Van Soest, P. J. (1982). The determination of digesta particle size in some herbivores. Animal Feed Science and Technology 7, 35-44.

Ulyatt, M. J., Dellow, D. W., John, A., Reid, C. S. W. \& Waghorn, G. C. (1986). The contribution of chewing, during eating and rumination, to the clearance of digesta from the rumino-reticulum. In Control of Digestion and Metabolism in Ruminants, pp. 498-515 [L. P. Milligan, W. L. Grovum and A. Dobson, editors]. Englewood Cliffs New Jersey: Prentice-Hall.

Ulyat1, M. J., Dellow, D. W., Reid, C. S. W. and Bauchop, T. (1975). Structure and function of the large intestine of ruminants. In Digestion and Metabolism in the Ruminant, pp. 119-133 [I. W. McDonald and A. C. I. Warner, editors]. Armidale, Australia: University of New England Publishing Unit.

Ulyatt, M. V., Baldwin, R. L. \& Koong, L. V. (1976). The basis of nutritive value, a modelling approach. Proceedings of the New Zealand Society of Animal Production 36, 140-149.

Van Soest, P. J. [editor] (1982). In Nutritional Ecology of the Ruminant, pp. 39-58. Corvallis, Or.: O and B Books, Inc.

Welch, J. G. \& Smith, A. M. (1978). Particle sizes passed from the rumen. Journal of Animal Science 46, 309-312.

Weston, R. H. \& Cantle, J. A. (1984). Movement of undigested plant particle fractions through the stomach of roughage fed young sheep. Canadian Journal of Animal Science 64, Suppl., 322-323.

Weston, R. H. \& Kennedy, P. M. (1984). Various aspects of reticulo-rumen digesta particle size. In Techniques in Particle Size Analysis of Feed and Digesta in Ruminants, pp. 1-17 [P. M. Kennedy, editor]. Alberta, Canada: Canadian Society of Animal Science. 